\title{
Trace elements in pegmatite-hosted titanite from the Petrovitsa Pb-Zn deposit, South Bulgaria
}

\author{
RossitsA D. VASSILEVA ${ }^{1}$, VALENTIN GROZDEV ${ }^{1}$,
} GEORGI MILENKOV ${ }^{1}$

${ }^{1}$ Geological Institute, Bulgarian Academy of Sciences; rosivas@geology.bas.bg

Rich skarn-ore metasomatic bodies and quartz-sulphide veins hosted by high crystalline metamorphic complex are the main base metal source in the Madan $\mathrm{Pb}-\mathrm{Zn}$ deposits, Central Rhodopes. Apart from that, abundant massive bodies (up to 2 m) with pegmatitic nature are commonly observed as concordant or crosscutting injections relative to the country rocks. In attempt to evaluate the potential of these intrusions for strategic metals an ongoing compositional study is taking place. Here we present LA-ICP-MS trace element signature of pegmatite-hosted titanite crystals, formed near the lithological contacts with skarnified and mineralized marbles in Petrovitsa deposit. The pegmatite body is composed mainly of K-feldspar and some plagioclase. Minor epidote and clinopyroxene complement the association on places.

Titanite is an important repository mineral for REE and HFSE in metamorphic and magmatic environments. The studied euchedral crystals are LREE-Y-enriched with increased incorporation of large number of elements (in ppm), most significant of which are: $\mathrm{Y}$ (1496), $\mathrm{Zr}$ (634), $\mathrm{Nb}$ (735), $\mathrm{La}$ (775), Ce (2225), Pr (307), Nd (1303), Sm (302), Eu (60), Gd (291), Tb (45), Dy (274), Ho (51), Er (147), Tm (21), Yb (133), Lu (17), Hf (32), Ta (74), Th (407), U (217). The $\Sigma$ REE ranges from $3940-7400 \mathrm{ppm}$. The $\mathrm{Th} / \mathrm{U}$ ratio reaches 2.60 , while $\mathrm{Lu} / \mathrm{Hf}$ averages $\sim 0.60$. Crystallization in feldsparbearing environment leads to structural patrition of the elements, thus titanite is LILE depleted ( $\mathrm{Rb} \sim 0.4, \mathrm{Sr} 32, \mathrm{Ba}$ $\sim 3$, Cs $\sim 0.15$ ), showing negative Eu-anomaly in the chondritenormalised pattern. The average metals incorporation is presented by: Mn (841), V (478), Cr (564), Ni (270), Cu ( 25), Zn (31), Ga (55), Ge (66), Mo (36), Sn (75), W (58), $\mathrm{Pb}$ (5.7), $\mathrm{Bi} \sim 3 \mathrm{ppm}$. Based on the chemical composition, the substitution mechanism in the octahedral site is $\mathrm{Al}^{3+}+\mathrm{Nb}^{5+}=2 \mathrm{Ti}$.

The combination of the morphological features, fracturefillings in some crystals, $\mathrm{Zr}$-content, $\mathrm{Th} / \mathrm{U}$ ratio and the geological envoronment suggest magmatic origin, although metamorphic and hydrothermal titanites from the Madan deposits are described as well.

Acknowledgements. The study is financed by the KP-06N34/4 project of the Bulgarian National Science Fund 